\title{
PENINGKATAN GENETIK MELALUI TEKNOLOGI IB DAN PENINGKATAN BOBOT BADAN MELALUI PEMBERIAN PAKAN LENGKAP DENGAN DQW PADA DOMBA MERINO DI TASIKMALAYA
}

\author{
SAIFUL RAHMAN, DIAN ARFIENA, CANDRA NURAINI \\ Program Studi Agribisnis, Program Pascasarjana, Universitas Siliwangi \\ *E-mail: saifulrahman321@gmail.com
}

\begin{abstract}
ABSTRAK
Penelitian ini bertujuan untuk mengetahui peningkatan genetik melalui teknologi IB dan peningkatan bobot badan domba merino melalui pemberian pakan lengkap dengan DQW yang diterapkan oleh para peternak domba merino di wilayah Tasikmalaya. Hasil dari penelitian ini memberikan gambaran bahwa para peternak domba merino di wilayah Tasikmalaya berhasil menguasai teknik reproduksi dan melakukan peningkatan genetik domba merino melalui teknologi IB. Selain itu dried quail waste (DQW) memiliki potensi besar sebagai bahan pakan pengganti, karena dari analisis laboratorium dried quail waste (DQW) yang difermentasi dengan penambahan onggok dan tetes mengandung protein kasar $25.10 \%$. Pemberian substitusi pakan dengan fermentasi DQW sebesar 5\% (P1) dapat memberikan pertambahan bobot badan sebesar 150,80g / ekor/ hari, P0: 79,37g / ekor/ hari dan P2: $103,18 \mathrm{~g} /$ ekor/ hari. Berdasarkan hasil penelitian ini disimpulkan bahwa, pemberian substitusi pakan fermentasi $\mathrm{DQW}$ berpengaruh nyata pada pertambahan bobot badan domba merino $(\mathrm{P}<0,05)$ di wilayah Tasikmalaya.
\end{abstract}

Kata Kunci: IB Domba Merino, DQW Domba Merino.

\begin{abstract}
This study aims to determine genetic enhancement through AI technology and increase body weight of merino sheep through complete feeding with $D Q W$ which is applied by merino sheep breeders in the Tasikmalaya region. The results of this study illustrate that the merino sheep breeders in the Tasikmalaya region have successfully mastered reproductive techniques and carried out genetic enhancement of merino sheep through IB technology. Besides that, dried quail waste $(D Q W)$ has great potential as a substitute for feed, because from laboratory analysis, dried quail waste (DQW) which is fermented with the addition of onggok and drops contains $25.10 \%$ crude protein. Provision of feed substitution with DQW fermentation of 5\% (P1) can give body weight gain of $150.80 \mathrm{~g} /$ head / day, P0: $79.37 \mathrm{~g} / \mathrm{head} /$ day and P2: $103.18 \mathrm{~g} /$ head / day. Based on the results of this study, it was concluded that the substitution of $D Q W$ fermented feed significantly affected the weight gain of merino sheep $(P<0.05)$ in the Tasikmalaya region.
\end{abstract}

Keywords: IB Merino Sheep, DQW Merino Sheep.

\section{PENDAHULUAN}

Domba yang kita kenal sekarang merupakan hasil dometikasi manusia yang sejarahnya diturunkan dari 3 jenis domba liar, yaitu Mouflon (Ovis musimon) yang berasal dari Eropa Selatan dan Asia Kecil, Argali (Ovis amon) berasal dari Asia Tenggara, Urial
(Ovis vignei) yang berasal dari Asia. ${ }^{1}$ Domba merupakan satu komoditas pertanian yang dimiliki hampir seluruh dunia dan Indonesia merupakan salah satu negara

\footnotetext{
1 Adnyana IDP. A dan Pratiwi TW, Modul Bahan Ajar Fisiologi Reproduksi-Siklus Reproduksi, Jurnal, (Malang: UB Media Press, 2013).
} 
yang dapat mengendalikan produksi ternak domba potong untuk menghadapai globalisasai hasil pertanian $2020 .^{2}$

Indonesia merupakan negara tropis dengan sumber alam yang mendukung, yaitu memiliki iklim tropis yang sesuai bagi pengembangan ternak domba, tanah yang luas dan produksi hijauan yang berlimpah pada musim penghujan cukup untuk memelihara 100 juta ternak domba atau 10 kali dari populasi yang ada sekarang, namun pada musim kemarau, hijauan berkurang sehingga para peternak enggan untuk beternak.3

Wilayah Tasikmalaya memiliki banyak persawahan dimana permasalahan pada saat panen jumlah jerami yang dihasilkan akan melimpah, dan jerami ini tidak diolah menjadi pakan ternak, tetapi langsung dibakar. Keunggulan complete feed (CF) adalah selain mengandung nutrisi yang seimbang dibandingkan pakan lain dan harga lebih murah. Hal ini disebabkan complete feed dibuat dari limbah pertanian dan limbah agroindustri ditambah suplementasi bahan bernilai nutrisi tinggi. Keunggulan lain adalah 1) peningkatan berat badan domba 250-300 gram/hari/ekor 2) ekonomis dan praktis (1

\footnotetext{
2 Bambang A.M, Memelihara Domba, (Yogyakarta: Penerbit Kanisius, 1993).

Bambang S, Beternak Domba, (Jakarta: Penebar Swadaya, 1990).
}

ekor domba butuh $1 \mathrm{~kg}$ ) dengan harga $\mathrm{Rp}$. 900 - Rp. 1000,- 3) waktu penggemukan pendek (3-4 bulan) 4) hemat tenaga kerja (I orang untuk 100 - 150 ekor domba) dan 5) mudah diaplikasikan.

Tasikmalaya merupakan daerah dingin yang sangat potensial untuk pengembangan ternak domba. Menurut data Dinas Peternakan Kota Tasikmlaya tahun 2017 populasi ternak domba 740.269 ekor dan lebih dari 6.001 ekor berada di wilayah Tasikmalaya. Namun perkembangan dan populasinya cenderung menurun akibat jumlah pejantan yang terbatas sehingga sering kawin antar keluarga (inbreeding) menyebabkan pertumbuhan domba terhambat, kematian tinggi. Keadaan ini menjadi parah saat Hari Raya Qurban yaitu terjadi pengeluaran pejantan muda secara besar-besaran. Peternak banyak yang tidak mempunyai pejantan sehingga persentase kebuntingan menjadi rendah dan jarak beranak cukup panjang. Untuk meningkatkan populasi dan mutu genetik domba di Tasikmalaya, perlu ditingkatkan kelahirannya menjadi 2 kali setahun dan jumlah cempe yang dilahirkan mencapai 4 ekor sekelahiran, sehingga dalam kurun waktu 12-14 bulan diharapkan induk domba dapat menghasilkan anak 6-8 ekor Salah satu Teknologi tepat guna untuk memperbaiki 
mutu genetik domba dalam meghasilkan daging adalah Inseminasi Buatan (IB) menggunakan semen segar maupun semen beku.

Domba merino merupakan domba tipe pedaging dan penghasil wol terbaik yang berasal dari Australia dengan berat badan dewasa dapat mencapai 150-200 kg, sedangkan pada umur 6 bulan beratnya mencapai 45-50kg dan menghasilkan bulu yang dapat diambil dalam 3 bulan sekali seberat $4 \mathrm{~kg}$. Salah satu upaya untuk menghasilkan bibit domba yaitu mengawinkan secara alam dan belum melaksanakan dan mengenal teknologi IB pada domba. Domba yang dipelihara oleh peteranak di Tasikmalaya sebagian besar adalah domba lokal yang ditandai dengan tinggi badan $60-70 \mathrm{~cm}$, dan berat badan 20 - $40 \mathrm{~kg}$ sehingga perlu diperbaiki genetiknya menggunakan pejantan unggul yang menghasilkan daging dan susu. dan dihindarkan dari perkawinan inbreeding.

Teknologi IB pada domba lokal menggunakan pejantan domba Merino, diharapkan merupakan contoh produksi cempe kualitas unggul penghasil susu dan daging serta teknologi pengolahan pasca panen susu domba. Diharapkan peternak lain terutama kaum muda akan tertarik untuk memelihara domba merino untuk meningkatkan gizi masyarakat pedesaan sekaligus menciptakan lapangan pekerjaan di desa tersebut dan tidak perlu lagi terjadi urban ke kota.

Selain itu ternak domba merupakan komoditi ternak yang mempunyai potensi besar untuk dikembangkan. Hal ini karena ternak domba harganya relatif murah jika dibandingkan dengan ternak ruminansia besar. Selain itu dapat dilakukan dengan modal yang relatif kecil, sehingga komoditi ini sangat cocok untuk peternak terutama skala kecil. Domba juga lebih efisien dalam memanfaatkan pakan dengan pertumbuhan yang lebih cepat dibanding dengan ruminansia besar.

Produktivitas dan kualitas hasil ternak sangat ditentukan oleh kualitas pakan. Saat ini harga bahan pakan ternak semakin meningkat dan biaya pakan yang di keluarkan untuk usaha peternakan mencapai $80 \%$ dari biaya produksi. Salah satu alternatif untuk menekan biaya pakan ternak domba tersebut dapat dilakukan dengan pemanfaatan limbah kotoran puyuh.

Kotoran puyuh memiliki kandungan zat makanan yang bervariasi namun kurang palatable. Maka diperlukan perlakuan terlebih dahulu pada kotoran puyuh tersebut sebelum digunakan sebagai substitusi pakan ternak dengan melakukan fermentasi. Tujuan dalam proses 
fermentasi ini yaitu untuk mengawetkan bahan pangan serta meningkatkan kandungan zat makanan, selain itu fermentasi juga ditujukan untuk meningkatkan palatable. Proses fermentasi yang dilakukan dapat memecah komponen kompleks menjadi zat-zat yang lebih sederhana sehingga lebih mudah dicerna, disamping itu dapat mensintesa beberapa vitamin yang kompleks dan faktor-faktor pertumbuhan seperti riboflavin dan provitamin A.

Berdasarkan latar belakang tersebut peneliti tertarik untuk melakukan penelitian dengan mengangkat permasalahan yang dibuat dalam judul penelitian yaitu "Peningkatan Genetik Melalui Teknologi IB dan Peningkatan Bobot Badan Melalui Pemberian Pakan Lengkap Dengan DQW pada Domba Merino di Tasikmalaya".

\section{MATERI DAN METODE}

\section{Peningkatan Genetik Melalui Teknologi}

\section{IB pada Domba Merino di Tasikmalaya}

Metode pendekatan yang dilakukan dalam program ini adalah memberikan wawasan, ilmu pengetahuan, teknologi tepat guna yang sederhana dan mudah untuk diaplikasikan serta dikembangkan kepada peternak domba merino yang telah dipilih. Selain itu bimbingan dan pendampingan akan diberikan kepada peternak domba merino sehingga dapat dipastikan kegiatan berjalan seperti yang direncanakan. Sesuai dengan prioritas masalah yang telah disepakati maka beberapa kegiatan dirancang dalam kegiatan ini untuk menyelesaikan permasalahan yang ada.

Untuk mencapai keberhasilan program ini dilakukan untuk menjawab permasalahan yang ada melalui pendidikan dan pelatihan untuk meningkatkan genetik domba Merino melalui IB yaitu sebagai berikut:

a. Pengenalan kandang yang sesuai dengan standart

b. Pengenalan domba merino sebagai domba yang mempunyai peningkatan berat badannya 250 sampai 300 gram/ekor/hari dan menghasilkan wol.

c. Pengolahan pakan menggunakan bahan baku pakan lokal.

d. Pembekalan ilmu pengetahuan tentang:

1) Pengenalan bentuk kandang.

2) Pengenalan ragam domba.

3) Pengenalan domba merino (penghasil daging dan wol).

4) Pengenalan pejantan merino (penghasil daging dan wol) yang 
akan digunakan memperbaiki genetik domba lokal.

5) Pengenalan teknik superovulasi, sinkronisasi birahi dan IB pada domba menggunakan semen pejantan merino yang berkualitas ekspor untuk perbaikan genetik dan meningkatkan populasi.

e. Praktek

1) Praktek dan pelatihan pengambilan semen pejantan merino dan pemeriksaan kualitas dan kuantitas.

2) Praktek dan latihan pembuatan diluter/ pengencer semen pejantan Merino.

3) Pembuatan pakan olahan fermentasi.

f. Akhir program dievaluasi dengan cara:

1) Diuji pre dan post test setelah mendapatkan teknologi IB untuk meningkatkan genetik domba dengan jumlah mencapai 4 ekor sekelahiran dengan waktu beranak 2 kali dalam setahun.

2) Mencatat hasil superovulasi dan IB meliputi:

a) Jumlah dan bobot cempe lahir merino 4 sampai $5,8 \mathrm{~kg}$.

b) Memilih cempe kualitas unggul “peranakan merino" sebagai pemacek untuk pejantan dan indukan.

c) Adanya kesulitan waktu melahirkan dan penyakit reproduksi.

\section{Peningkatan Bobot Badan Melalui} Pemberian Pakan Lengkap Dengan DQW pada Domba Merino di Tasikmalaya

a. Domba Merino yang berjumlah 9 ekor, yang dikelompokan berdasarkan berat badan yang relatif sama, yaitu $13 \mathrm{~kg}-15 \mathrm{~kg}, 16 \mathrm{~kg}$, dan lebih dari $17 \mathrm{~kg}$.

b. Rumput gajah yang diperoleh dari sekitar peternakan.

c. Konsentrat yang diproduksi oleh JAPFA Comfeed (PK $16 \%)$

d. Substitusi pakan yang tebuat dari Dried Quail Waste, Onggok dan Tetes.

Metode penelitian yang digunakan adalah percobaan laboratorium (experimental laboratory) dan Percobaan in-vivo. Perlakuan dengan penambahan substitusi pakan lengkap dari Dried Quail Waste. Metode yang digunakan dalam penelitian ini meliputi pembuatan substitusi pakan, uji laboratorium, pengaplikasian paba domba Merino. 
Substitusi yang telah difermentasi dan telah dianalisis di laboratorium, siap diberikan pada tenak dengan perlakuan sebagai berikut:

a. P0: $60 \%$ Rumput Gajah (1,2kg/ekor), $40 \%$ Konsentrat (0,8kg/ekor).

b. P1: $60 \%$ Rumput Gajah (1,2kg/ekor), $35 \%$ Konsentrat (0,7kg/ekor), $5 \%$ fermentasi DQW (0,1 kg/ekor).

c. P2: $60 \%$ Rumput Gajah (1,2kg/ekor), $30 \%$ Konsentrat (0,6kg/ekor), $10 \%$ fermentasi DQW (0,2kg/ekor).

Sementara itu variabel yang diamati dalam penelitian ini adalah pertambahan bobot badan domba Merino. Data yang diperoleh akan diuji dengan analisis data RAK (Rancangan Acak Kelompok) dan apabila terdapat perbedaan yang nyata akan diteruskan dengan uji BNT.

\section{HASIL PENELITIAN}

Berdasarkan prioritas masalah yang telah disepakati dengan para peternak domba Merino di Tasikmalaya maka beberapa tahap kegiatan yang dilaksanakan dalam penelitian ini untuk menyelesaikan permasalahan yang ada. Kegiatan-kegiatan yang telah dilaksanakan antara lain:

\section{Peningkatan Genetik Melalui Teknologi IB pada Domba Merino di Tasikmalaya}

Upaya untuk meningkatkan genetik domba Merino yang dikelola oleh para peternak di Tasikmalaya, maka peneliti melakukan beberapa langkah sebagai berikut:

a. Pelatihan Manajemen Produksi Pelatihan manajemen produksi dengan pemberian modul-modul, Pembekalan Ilmu Pengetahuan tentang Pengenalan bentuk kandang, (2) Pengenalan ragam domba, (3) Pengenalan domba merino (penghasil daging dan wol), (4) Pengenalan pejantan merino (penghasil daging dan wol) yang akan digunakan memperbaiki genetik domba lokal,

Pengenalan teknik superovulasi, sinkronisasi birahi dan IB pada domba menggunakan semen pejantan merino yang berkualitas ekspor untuk perbaikan genetik dan meningkatkan populasi.

Kegiatan pembukuan pada kegiatan produksi dan keuangan 
akan menguntungkan karena

dapat meningkatkan efisiensi biaya, tenaga dan waktu yang dicurahkan dalam kegiatan berternak dengan adanya takaran yang tepat dan sesuai untuk masing-masing aplikasi. Selain itu, evaluasi dan perbaikan kegiatan peternak di periode selanjutnya akan didasarkan pada hasil kegiatan pembukuan tersebut.

Situasi pembekalan ilmu pengetahuan tentang

Pengenalan bentuk kandang, (2)

Pengenalan ragam domba, (3)

Pengenalan domba merino (penghasil daging dan wol), (4) Pengenalan pejantan merino (penghasil daging dan wol) yang akan digunakan memperbaiki genetik domba lokal,

Pengenalan teknik superovulasi, sinkronisasi birahi dan IB pada domba menggunakan semen pejantan merino yang berkualitas ekspor untuk perbaikan genetik dan meningkatkan populasi.

b. Praktek dan pelatihan Managemen Reproduksi

Praktek dan Pelatihan manajemen Reproduksi dilakukan dengan pemberian Praktek dan pelatihan, Pembekalan Ilmu Pengetahuan tentang (1) Praktek dan pelatihan pengambilan semen pejantan merino dan emeriksaan kualitas dan kuantitas, (2) Praktek dan latihan pembuatan diluter/ pengencer semen pejantan Merino, (3) Praktek teknik superovulasi, sinkronisasi birahi dan IB pada domba menggunakan semen pejantan merino yang berkualitas ekspor untuk perbaikan genetic dan meningkatkan populasi, (4) Diagnosa kebuntingan secara dini, (5) Pembuatan pupuk bokhasi dan pupuk cair ramah lingkungan. 
Penyerentakan birahi dan Inseminasi Buatan pada Domba Merino

\begin{tabular}{ccc}
\hline Jumlah Induk & \multicolumn{2}{c}{ Induk Domba Birahi pada Penyuntikan PGF2 $\alpha$} \\
\cline { 2 - 3 } Domba & Pertama & Kedua \\
\hline 20 ekor & $9(45 \%)$ & $15(75 \%)$ \\
\hline
\end{tabular}

Jumlah Induk Domba Bunting

\begin{tabular}{cccccc}
\hline \multirow{2}{*}{$\begin{array}{c}\text { Tdk } \\
\text { Bunting }\end{array}$} & \multirow{2}{*}{ Bunting } & Anak Hidup & Anak Mati & \multicolumn{2}{c}{ Jenis Kelamin } \\
\cline { 4 - 6 } $\begin{array}{l}3 \text { ekor } \\
(15 \%)\end{array}$ & 17 ekor $(85 \%)$ & 45 ekor $(86 \%)$ & $\begin{array}{c}7 \text { ekor } \\
(13 \%)\end{array}$ & 23 ekor $(51 \%)$ & $\begin{array}{c}22 \text { ekor } \\
(48 \%)\end{array}$ \\
\hline
\end{tabular}

c. Monitoring dan Evaluasi

$\begin{array}{lr}\text { Untuk } & \text { mengetahui } \\ \text { derajat } & \text { keberhasilan } \\ \text { penelitian ini maka dilakukan } & \text { monitoring } \text { dan } \\ \text { kegiatan } & \text { Monitoring } \\ \text { evaluasi. } & \text { dilakukan setiap bulan untuk } \\ \text { memastikan kegiatan yang } & \text { telah sesuai } \\ \text { dilaksanakan } & \text { telah } \\ \text { dengan yang } & \\ \text { direncanakan }\end{array}$

Pada akhir kegiatan akan dilakukan evaluasi secara keseluruhan untuk mengetahui derajat keberhasilan kegiatan berdasarkan target yang telah ditetapkan. Evaluasi awal pertemuan dengan menggunakan pre test dan post test menunjukkan adanya peningkatan kemampuan dari peternak. Monitoring dan
Evaluasi yang masih berjalan adalah mencatat pertambahan berat badan penggemukan domba bakalan hasil IB hingga domba tersebut siap untuk dijual, dan adanya kasus penyakit.

\section{Peningkatan Bobot Badan Melalui Pemberian Pakan} Lengkap Dengan DQW pada Domba Merino di Tasikmalaya

a. Kandungan Nutrisi Fermentasi Dried Quail Waste

Berdasarkan hasil uji laboratorium dapat diketahui nutrisi yang terkandung dalam fermentasi Dried Quail Waste (DQW) sebagaimana tercantum dalam tabel berikut: 
Kandungan Nutrisi

\begin{tabular}{|c|c|c|c|c|c|}
\hline \multirow{2}{*}{ No. } & \multirow{2}{*}{ Bahan Pakan } & \multicolumn{4}{|c|}{ Kandungan Zat Makanan } \\
\hline & & $\mathrm{BK}(\%)$ & Abu $(\%)$ & $\mathrm{PK}(\%)$ & SK $(\%)$ \\
\hline 1 & Kotoran Puyuh & 67,69 & 29,91 & 33,05 & 13,40 \\
\hline 2 & Subtitusi sebelum difermentasi & 48,56 & 22,85 & 23,27 & 12,65 \\
\hline 3 & Subtitusi setelah difermentasi & 50,36 & 20,47 & 25,10 & 12,57 \\
\hline
\end{tabular}

Berdasarkan tabel tersebut dapat kita ketahui bahwa Dried Quail Waste (DQW) memiliki potensi yang cukup besar sebagai bahan substitusi pakan. Berdasarkan penelitian terdahulu kandungan Protein Kasar pada Feses Puyuh Terfermentasi $(17,40 \%)$ lebih rendah daripada kandungan protein Kasar pada Feses Puyuh Segar $(22,92 \%)$ hal ini dikarenakan adanya penambahan onggok kering dalam proses pembuatan fermentasi feses puyuh (Widhya dan Ramayulis, 2009). b. Pertambahan Bobot Badan Domba

Berdasarkan penelitian yang telah ada, hasil evaluasi demplot pemberian feses puyuh fermentasi untuk konsentrat sapi didapatkan data laju pertambahan berat badan sapi (PBB) dari 0,52 $\mathrm{kg} / \mathrm{hari}$ menjadi $0,64 \mathrm{~kg} / \mathrm{hari}$ atau meningkat $24 \%$.

Pertambahan Bobot Badan Domba Gram/ekor/hari

\begin{tabular}{ccccc}
\hline \multirow{2}{*}{ Perlakuan } & \multicolumn{3}{c}{ Kelompok } & \multirow{2}{*}{ Rata-Rata } \\
\cline { 2 - 4 } & 1 & 2 & 3 & 79,37 \\
\hline P0 & 71,43 & 71,43 & 95,24 & 150,80 \\
\hline P1 & 142,86 & 142,86 & 166,67 & 103,18 \\
\hline P2 & 95,24 & 95,24 & 119,05 & \\
\hline
\end{tabular}

Hasil analisis statistik Pemberian Substitusi Pakan Lengkap Dari Dried Quail Waste (DQW) Terhadap Pertambahan Bobot Badan Domba Merino berpengaruh sangat nyata terhadap $\mathrm{PBB}$ Domba $(\mathrm{P}<0,01)$, yaitu pertambahan bobot badan domba pada P1 $(150,80 \mathrm{~g})$ lebih

\section{A. KESIMPULAN}

besar dari P2 $(103,18 \mathrm{~g})$ dan P0 $(79,37 \mathrm{~g})$, dan P2 lebih besar dari P0.

Pemberian substitusi pakan lengkap dari Dried Quail Waste pada domba Merino, memiliki dampak positif yaitu kecenderungan peningkatan berat badan domba Merino. 
1. Peningkatan genetik melalui teknologi IB pada domba Merino di Tasikmalaya berdasarkan dari hasil penelitian yang telah dilaksanakan maka dapat diambil bahwa para peternak mampu menguasai teknik manajemen produksi dan reproduksi domba Merino.

2. Berdasarkan hasil penelitian ini dapat disimpulkan bahwa terdapat pengaruh yang sangat nyata terhadap pertambahan bobot badan domba Merino $(\mathrm{P}<0,01)$. Pemberian substitusi pakan dari DQW sebesar 5\% dari pakan basal dapat menberikan pertambahan bobot badan sebesar 150,80g/ekor/hari dan konsumsi pakan $1,79 \mathrm{~kg} / \mathrm{ekor} / \mathrm{hari}$.

\section{DAFTAR PUSTAKA}

A. Parakkasi. 1999. Ilmu Nutrisi dan Makanan Ternak Ruminan. Jakarta: UI Press.

Adnyana IDP. A, Pratiwi TW. 2013. Modul Bahan Ajar Fisiologi Reproduksi-Siklus Reproduksi. Malang: UB Media Press.

Bambang A.M. 1993. Memelihara Domba. Yogyakarta: Penerbit Kanisius.

Bambang S. 1990. Beternak Domba. Jakarta: Penebar Swadaya.

Cahyono B. 1998. Beternak Domba dan Kambing. Yogyakarta: Penerbit Kanisius.

Muslimin Z, Meles DK dan Wurlina. 2011. Formula Pakan Tanpa Hijauan pada Kambing, Domba dan Sapi. Komunikasi.

Ramaiyulis, P.S. Noor, dan Salvia. 2007. Penerapan Teknologi Defaunasi dan Suplementasi Permen Sapi Untuk Meningkatkan Produktivitas Reproduksi Sapi Potong di Kawasan Pembibitan Sapi Simental. Baso. J Lumbung VI.

Widhya dan Ramaiyulis. 2009. Optimalisasi Pemanfaatan Limbah Kulit Buah Kakao Menjadi Pakan Kaya Protein Sel Tunggal Dengan, Penel Strategis. Payakumbuh: Politeknik Pertanian Negeri Payakumbuh. 